\title{
Challenges Associated with the Implementation of Knowledge Management in Nigerian Tertiary Institutions
}

\author{
Ruby N. Ike ${ }^{1}$, Emmanuel K. Agbaeze ${ }^{1}$, Ben E. Udoh ${ }^{1} \&$ Bamidele S. Adeleke ${ }^{2}$ \\ ${ }^{1}$ Department of Management, University of Nigeria, Enugu Campus, Nigeria \\ ${ }^{2}$ Department of Marketing, Ladoke Akintola University of Technology, Nigeria \\ Correspondence: Ruby N. Ike, Department of Management, University of Nigeria, Enugu Campus, Nigeria
}

Received: September 30, 2019

Accepted: December 14, 2019 Online Published: December 23, 2019

doi:10.5430/ijhe.v8n8p70

URL: https://doi.org/10.5430/ijhe.v8n8p70

\begin{abstract}
This study examined the challenges associated with knowledge management implementation and academic staff retention in selected tertiary institutions in South East, Nigeria. The research design adopted was a cross-sectional survey design. The main instrument used for data collection was questionnaire. The population consisted of 7,423 academic staff of the 10 randomly selected institutions in the South East Nigeria. A total sample size of 555 was drawn from the population. The instrument was checked for reliability using Cronbach method and the reliability co-efficient result of 0.915 showed that the instrument had high degree of item reliability. The hypothesis formulated was tested using Friedman chi-square statistics. The findings indicate that there is positive significant challenge in knowledge management implementation and academic staff retention in selected tertiary institution. The study concluded that lack of Knowledge Management implementation has posed a great challenge in academic staff retention in tertiary institutions. It was advised that tertiary institutions in Nigeria should adequately manage the process of knowledge acquisition, sharing and development so as to enjoy a Stella performance
\end{abstract}

Keywords: knowledge management, academic staff, challenges, organizational culture

\section{Introduction}

Knowledge Management (KM) is an organizational process that aims to create a centralized knowledge source within the organization that acquires, assimilates, distributes, integrates, shares, retrieves and reuses the internal and external, explicit and tacit to bring innovation in the organization in the form of the product, people and organizational process (Akram et al., 2011). Knowledge Management is concerned with storing and sharing the wisdom, understanding and expertise accumulated in an organization about its processes, techniques and operations. Knowledge Management promotes the sharing of knowledge by linking people with people and by linking them to information so that they learn from documented experiences (Scarborough \& Preton, 1999). Knowledge Management is linked within the culture of organizations. Organizations that rapidly capture and implement new knowledge across the organization will be able to foster innovation as compared to those organizations that do not focus on this aspect (Cavusgil et.al, 2003). Messa and Testa (2004) state that organizations must develop the receptors that gain or absorb the external knowledge and this activity is strongly related to the innovation capability.

Knowledge Management research and practice have grown at a dramatic pace in the last few years (Gray\& Meister, 2006). Given the intensively competitive climate, organizations position themselves as knowledge-driven companies, seeking to leverage their knowledge resources in order to achieve competitive advantage. However, organizations are confronted by a variety of knowledge management (KM) problems. These problems can be addressed both by identifying the causes and by developing solutions (Alavi \& Leidner 2001). The problems identified cover the four KM processes of creation, storage/retrieval, transfer and application. Davenport and Prusak (1988) argue that the biggest challenges in most knowledge Management efforts lie in changing people's work habits. The challenge lies in getting people to articulate and share knowledge face to face. The challenge is in creating knowledge management strategies that focus on developing knowledge sharing systems that are dependent on employees. In addition, if, knowledge is power, then the owners of that knowledge will be protective of their knowledge, in the belief that they benefit more from hoarding their knowledge than sharing it. Knowledge Management has existed as an activity since the beginning of consciousness about knowledge itself. As a discipline/professional field however, Knowledge Management (KM) originated during the late ' 80 s and became prominent only with the rise of the Internet. Despite 
its tender age, changes in paradigms have already come to KM (Firestone, 2003). The first KM paradigm which some authors call The Old Knowledge Management (TOKM), because it has been superseded by a number of competing paradigms which are variants of a broader orientation called Second Generation Knowledge Management (SGKM). The variant called The New Knowledge Management (TNKM), originated by Firestone and McElroy (2003). These changes in KM are significant for Knowledge Technology (KT) because the reason why KT exists is to support Knowledge and KM processes of individuals and higher level systems such as groups, organizations, nations, and super-national entities (McElroy, 2003). The measure of KT's success or failure is how well it supports these processes. So, the agenda of KT is ultimately set by our understanding of KM, which provides the basis for our evaluation of the utility of KT offerings in helping us to solve the business, knowledge, and KM processing problems we encounter in everyday life.

Parlby and Taylor (2000) assert that the foremost purpose of knowledge management is to bring innovation. So, to bring innovation, organizations must identify knowledge capability, and richness. Through a proper knowledge distribution and sharing, organizations can bring about innovation. So, organizations must develop such channels within the organizations through which employees share their knowledge with one another. Plessis (2007), states that innovation depends upon knowledge. Through Knowledge Management activities, organizations find out the distance of knowledge from inside and outside the organizations. Organizations manage this knowledge in the form of data base, so that, they can ensure the availability of right type of knowledge to the right person at the right time. The Nigerians Tertiary Institutions faces a huge challenge in terms of skilled human resource capacity which has a debilitating effect on its ability to make strides in the socio-economic and political development. Ndulu (2004), states that while efforts have been made to address the problem, there seems to be little progress, due to a variety of reasons, particularly, the inadequate investment, in education and other training programs. Successful implementation of KM in the tertiary institutions remains the key to progress in these organizations. Tertiary institutions in Nigeria have continued to lose their best hands in the recent past, possibly as a result of some challenges which may affect the implementation of knowledge management. This study is set to identify the challenges associated with the implementation of Knowledge Management in selected tertiary institutions in South-East Nigeria. The present study tested the hypothesis that lack of knowledge management implementation contributed to a great challenge in academic staff retention in tertiary institutions. Also that the challenges associated with the implementation of Knowledge Management in selected tertiary institutions in South East, Nigeria are funding, culture of hoarding knowledge and impatience to understanding mentors (Amini et al, 2018).

\section{Methods}

The study adopts a cross-sectional survey design method. Survey means 'to view comprehensively and in detail' or the act of 'obtaining data for mapping' (Onodugo, Ugwuonah \& Ebinne, 2010). These are studies which sole aim is to examine the current opinions, behaviours and other characteristics of a group of people. It is an investigation into what currently exists in an area, at the time of the research, in their natural setting. The sources of data comprised of primary source. The information from the primary source consists of responses from the questionnaire administered to the academic staff from the selected institutions under study. One set of questionnaire was used for the study. The information elicited includes information on educational background, qualifications, positions, gender, age and number of years of service. The population of the study is 7,423 which consist of all the academic staff of tertiary institutions in the South East Nigeria. As a result, it was not possible to use the entire population, hence ten institutions in the South East Geopolitical Zone of Nigeria were selected. These institutions were purposively selected. The target population of this study consists of the academic staff of the ten selected institutions. 
Table 1. Population of the study

\begin{tabular}{ccc}
\hline State & Tertiary Institutions & No. of Academic Staff \\
\hline Abia & Federal University Umudike & 652 \\
“ & Abia State Polytechnic, Aba & 366 \\
Anambra & Nnamdi Azikwe University, Awka & 1,150 \\
“ & Nwafor Orizu College of Education, Nsugbe & 270 \\
Ebonyi & Ebonyi State University, Abakaliki & 1,605 \\
“ & Akanu Ibiam Polytechnic, Unwanna Afikpo. & 339 \\
Enugu & University of Nigeria, Nsukka & 1,519 \\
“ & Institute of Management and Technology, Enugu & 205 \\
Imo & Federal University of Technology, Owerri & 800 \\
“ & Imo State University Owerri & 517 \\
& Total & 7,423
\end{tabular}

The target population of the study includes all the academic staff of the selected institutions in the South East, Nigeria which stands at 7,423. Thus, using a finite population formula of Krejcie and Morgan (1970), the sample size was determined and a sample size of 555 was derived. The stratified random sampling sample technique was used. The major research instrument used in gathering data for this study was a structured questionnaire. This questionnaire had two (2) sections; question A was on general information concerning the respondents while section $\mathrm{B}$ directly addressed the research questions. Close ended and multiple choice questions were used. The questionnaire was administered to all the selected academic staff of the ten institutions. In order to ensure that the research instrument was valid the researcher ensured that the instrument measured the concepts it was supposed to measure. The questionnaire was vetted by experts in the Faculty of Business Administration University of Nigeria. A pilot survey was used to test 30 respondents selected from two universities (one federal and one state institution). Their responses, comments and preliminary analysis were used to modify and fine-tune the instrument. To ensure reliability of the data, the researcher administered the questionnaire in batches that yielded nearly equivalent responses. To ascertain that the instrument is reliable, the test-retest was adopted. The outcome of the test-retest was determined using Cronbach Alpha and the result was 0.915. Since the result was very high, thus we assert that the instrument was highly reliable.

\section{Data Analysis and Results}

Table 2 below shows that $78.37 \%$ of the distributed copies of the questionnaire were returned and used whereas $22.02 \%$ were not returned and were not used for the analysis

Table 2. Distribution and Return of the Questionnaire

\begin{tabular}{ccc}
\hline & Frequency & Percentage (\%) \\
\hline Returned & 435 & 78.38 \\
Not Returned & 120 & 21.62 \\
Total & 555 & 100
\end{tabular}

Table 3 below shows that thirty (30) respondents representing 6.90\%, were from Abia State Polytechnic, 75 respondents, representing 17.24\%, were from Ebonyi State University, 48 (11.03\%) respondents from FUTO, 28 respondents, representing 6.44\% were from Federal Poly Afikpo, 20 (4.60\%) respondents from IMT, 35 (8.05\%) respondents from Imo State University, 26 (5.98\%) respondents from Nwafor Orizu College of Education Nsugbe, $69(15.86 \%)$ respondents, from UNN, $45(10.34 \%)$ respondent from Federal University Umudike, and 59 (13.56\%) respondents from UNIZIK Awka campus. This implies that respondents from Ebonyi State University were more, followed by respondents from UNN and UNIZIK Awka which had 75, 69 and 59 respondents respectively. 
Table 3. School Distribution of respondents

\begin{tabular}{ccc}
\hline School & Frequency & Percentage (\%) \\
\hline Abia State polytechnic, Aba & 30 & 6.90 \\
Ebonyi State University & 75 & 17.24 \\
FUTO & 48 & 11.03 \\
Fed. Poly Afikpo & 28 & 6.44 \\
IMT Enugu & 20 & 4.60 \\
Imo State University & 35 & 8.05 \\
Nwafor Orizu College Education & 26 & 5.98 \\
UNN & 69 & 15.86 \\
Umudike Fed. University & 45 & 10.34 \\
UNIZIK Awka & 59 & 13.56 \\
Total & 435 & 100
\end{tabular}

Source; Field Survey, 2018

Two hundred and sixty (260) respondents representing $60.07 \%$ were male, whereas 175 respondents, representing $40.22 \%$ were female. This indicated that males were more than the females. The age distribution of the respondents showed that 94 respondents representing $22.00 \%$ were between the age of $25-30,100$ respondents with $23.08 \%$ were within the age bracket of $35-45$, while 241 respondents representing $55.40 \%$ were within the age bracket of 45 years and above. This implies that greater proportion of the respondents fall within the age of 45 years and above.

The collected data was presented using percentage tables, percentages, mean and standard deviations. The 5 Likert type questionnaires rating of Strongly Agreed (SA), Agreed (A), Undecided (U), Disagree (D) and Strongly Disagree (SD) were assigned numbers 5, 4, 3, 2 and 1 respectively. The formulated hypothesis was tested using Friedman Chi-square at a significance level of $0.05(5 \%)$. The decision rule was based on the sample mean greater than 3 for agreed and otherwise for disagreement.

Table 4. Challenges Associated with the Implementation of Knowledge Management

\begin{tabular}{ccccccccc}
\hline \multirow{2}{*}{ Questions } & $\begin{array}{c}\mathrm{SA}(5) \\
\text { Freq } \%\end{array}$ & $\begin{array}{c}\mathrm{A}(4) \\
\text { Freq } \%\end{array}$ & $\begin{array}{c}\mathrm{U}(3) \\
\text { Freq } \%\end{array}$ & $\begin{array}{c}\mathrm{D}(2) \\
\text { Freq } \%\end{array}$ & $\begin{array}{c}\mathrm{SD}(1) \\
\text { Freq } \%\end{array}$ & Total & Mean & SD \\
\hline \multirow{2}{*}{ Funding } & 214 & 102 & 38 & 40 & 41 & 435 & 3.93 & 1.34 \\
& 49.19 & 23.45 & 8.78 & 9.20 & 3.85 & 100 & & \\
Culture of hoarding knowledge & 89 & 164 & 59 & 72 & 51 & 435 & 3.39 & 1.30 \\
& 20.46 & 37.71 & 13.56 & 16.55 & 11.72 & 100 & & \\
Impatient to understanding mentors & 84 & 160 & 72 & 69 & 50 & 435 & 3.37 & 1.28 \\
Non-payment of salaries as at when & 19.32 & 36.78 & 16.55 & 15.86 & 11.49 & 100 & & \\
due & 104 & 147 & 51 & 78 & 55 & 435 & 3.38 & 1.36 \\
Lack of state-of-the-art equipment & 148 & 144 & 48 & 47 & 48 & 435 & 3.68 & 1.33 \\
to meet global standard & 34.02 & 33.10 & 11.04 & 10.80 & 11.04 & 100 & & \\
\hline
\end{tabular}

Table 4 shows the responses of the respondents on the challenges associated with the implementation of knowledge management. Five questions were formulated in that respect.

As regards to the question on funding, $214(49.19 \%)$ and $102(23.45 \%)$ respectively of the respondents, strongly agreed and agreed that funding poses a great challenge in the implementation of knowledge management respectively, $38(8.74 \%)$ of the respondents were undecided, while $40(9.20 \%)$ and $41(9.421 \%)$ of the respondents disagreed and strongly disagreed, respectively, that funding is a challenge. It is penitent to note, that mean value of 4.56 shows the high level of challenge fund poses on the implementation of knowledge management in our selected tertiary institutions. 
On the aspect of culture of hoarding knowledge, 89 (20.46\%) and 164 (37.71\%) respectively of the respondents strongly agreed and agreed that culture of hoarding knowledge was a challenge, respectively. $59(13.56 \%)$ of the respondents were undecided, while $72(16.55 \%)$ and $51(11.72 \%)$ of the respondents disagreed and strongly disagreed on the assertion respectively. In view of the mean of 3.39 based on our decision rule, it is penitent to note that the assertion is positive.

On the aspect of impatient to understanding mentors, $84(19.32 \%)$ and $160(36.78 \%)$ of the respondents strongly agreed and agreed on the assertion respectively. $72(16.55 \%)$ of the respondents were undecided, while $69(15.86 \%)$ and $50(11.49 \%)$ of the respondents disagreed and strongly disagreed, respectively, that impatient to understanding mentors is a challenge to the implementation of knowledge management.

As regards to the nonpayment of salaries as and when due as a major challenge to the knowledge management implementation, $104(23.91 \%)$ and $147(33.79 \%)$ respectively of the respondents strongly agreed and agreed that nonpayment of salaries as at when due is a major challenge in the implementation of knowledge management in selected tertiary Institutions. 51 (11.73\%) of the respondents were undecided, while $78(17.93 \%)$ and $55(12.55 \%)$ of the respondents disagreed and strongly disagreed, respectively, on the above statement.

Also, $148(34.02 \%)$ and $144(33.10 \%)$ of the respondents strongly agreed and agreed respectively that lack of the state-of-the-art equipment to meet global standard was a challenge. $48(11.04 \%)$ of the respondents were undecided, while $47(10.80 \%)$ and $48(11.04 \%)$ of the respondents, respectively, disagreed and strongly disagreed with the assertion. The high mean of 4.19 attested to that assertion showed that all the above were challenges to full implementation of knowledge management in tertiary institutions.

The present study tested the hypothesis that lack of knowledge management implementation contribute to a great challenge in academic staff retention in tertiary institutions. In testing this hypothesis, the data presented in Table 4 were tested using the Friedman Chi-Square test.

$H_{O}$ : lack of knowledge management implementation contributes to a great challenge in academic staff retention in tertiary institutions.

Table 5. Friedman Chi-Square Test Result for the Hypotheses

\begin{tabular}{cc}
\hline Statistic & Value \\
\hline $\mathrm{N}$ & 435 \\
Chi-Square & 726.661 \\
$\mathrm{Df}$ & 4 \\
Asymp. Sig. & .000 \\
\hline
\end{tabular}

The result presented in Table 5 shows that the calculated Friedman Chi-Square value is 726.661. This is greater than the critical chi-square value of 9.49. Having an asymptotic significance of $0.000<0.05$, this result is significant. Therefore, lack of Knowledge Management implementation has posed a great challenge in academic staff retention in tertiary institutions.

The objective of this study is to identify the challenges associated with the implementation of Knowledge Management in Nigerian tertiary institutions. In order to identify the above claim, five logical and sequential questions were raised. More than $50 \%$ of the questions raised in the objective agreed that funding, culture of hoarding knowledge, impatience to understanding mentors, nonpayment of salaries as and when due, and lack of the state-of-the-art equipment to meet global standard are the major challenges associated with the implementation of Knowledge Management in Nigerian tertiary institutions. The result confirmed that the calculated Friedman chi-square value of 726.661 at $\mathrm{df}=4$ is greater than the critical chi-square value of 9.49 , we reject the null hypotheses and accept the alternate hypotheses at $95 \%$ confidence level which state that lack of knowledge management implementation contributed to a great challenge in academic staff retention in tertiary institutions.

\section{Discussion}

This finding is in concordance with the finding of study carried out by Qu and Davidson (2010). WHO posit that the Knowledge Management challenges can be classified into three dimensions as below: structural (organization) challenges, human problems and technical problems. Another significant discovery of the study in the challenges of knowledge management is that of knowledge conversion problems which lies in the knowledge externalization processes. The respondents explained that the staff feels too difficult to express their experiences, although they know that it will benefit the junior staff. Moreover, Ju et al (2006) pointed out that inter-personal conflicts, 
competition among staff, lack of trust and relationships and intra- departmental conflicts complicate knowledge transfer.

This finding is also strengthened by the further observation of Qu and Davidson that information technology is a major challenge of knowledge management, in Nigerian tertiary institutions. This is supported by the respondents assertion that the system is out- dated and some work has to be done manually. The capacity of the hardware and software support is not enough, and the system is slow and always busy, sometimes it hangs. All the assertions collaborates the fact that structural, human and technical related causes are the major challenges that hinder the implementation Of Knowledge Management in our Nigerian tertiary institutions.

\section{Conclusion and Recommendation}

Conclusively, the findings from this study clearly indicate that organization structure and culture are the factors that affect Knowledge Management. The reward and incentives also has positive effect on academic staff retention. The study showed that there is positive significant challenges in Knowledge Management implementation and academic staff retention in selected tertiary institutions. The finding above emanated from the result of table $5\left(\mathrm{X}_{\text {cal }}^{2}=726.661>\right.$ $\left.\mathrm{X}_{\text {critical }}^{2}=9.49, \mathrm{p}<0.05\right)$. In line with the conclusions which emanated from findings, it is important that tertiary institutions in Nigeria should adequately manage the process of knowledge acquisition, sharing and development so as to enjoy a Stella performance among the league of institutions on the globe.

\section{Limitations}

A study of this nature to be carried out in this period of economic meltdown and security uncertainties is faced with a number of limitations. Some of these include: finance and attitude of some respondents that did not respond positively to the information required. As a result of the above factors, the researcher was constrained to limit the study to tertiary institutions in the South East, Nigeria rather than the entire country.

\section{References}

Akram K., Siddiqui, S.H, Nawaz M.A, Ghauri TA, \& Cheema, A.K.H. (2011). The role of knowledge management to bring innovation: an integrated approach. International Bulletin of Business Administration 11, 1-14.

Alavi M, \& Leidner D.E. (2001). Knowledge management and knowledge management systems: conceptual foundations and research issues. MIS Quarterly, 25(1), 107-136. https://doi.org/10.2307/3250961

Amini, N., Rezaei, T., \& Tavakoli, M. (2018). The study of mediator role of job satisfaction in organizational justice and citizenship behavior relationship in one of the Shiraz factories. UCT Journal of Social Sciences and Humanities Research, 6(04), 79-84.

Cavusgil ST, Calantone RJ, \& Zhoa Y. (2003). Tacit knowledge transfer and firm innovation capability. Journal of Business and Industrial Marketing. 18(1): 6-21. https://doi.org/10.1108/08858620310458615

Davenport, T.H, \& Prusak, L. (1988). Working knowledge how organizations manage what they know. Boston, M.A: Harvard Business School Press.

Firestone J.M. (2003). Enterprise Information Portals and Knowledge Management, Boston, MA: KMCI Press/Butterworth Heinemann.

Firestone, J.M, \& McElroy, M.W. (2003). Key Issues in the New Knowledge Management, Burlington, MA: KMCI Press/Butterworth Heinemann. https://doi.org/10.1016/B978-0-7506-7655-7.50013-4

Gray, P.H, \& Meister, D.B. (2006). Knowledge Sourcing Methods. Information and Management, 43(1), 142-156. https://doi.org/10.1016/j.im.2005.03.002

Ju, T.L, Li, C.Y, \& Lee, T.S. (2006). A contingency model for knowledge management capability and innovation. Industrial Management and Data System, 106(6), 855- 877. https://doi.org/10.1108/02635570610671524

Kinner, T.C, \& Taylor, J.R. (1983). Market Research. Boston: McGraw - Hill.

Krejcie R.V, \& Morgan D.W. (1970). Determining sample size for research activities. Educational and Psychological Measurement 30: 607-610. https://doi.org/10.1177/001316447003000308

McElroy M.W. (2003). The New Knowledge Management: Complexity, Learning, and Sustainable Innovation, Boston, MA: KMCI Press/Butterworth-Heinemann.

Messa, S. \& Testa, S. (2004). Innovation or Imitation? Benchmarking: A Knowledge Management Process to Innovate Services. Benchmarking: An International Journal, 11(6), 610-620. https://doi.org/10.1108/14635770410566519 
Ndulu, B.J. (2004). Human Capital Flight: Stratification, Globalisation, and the Challenges to Tertiary Education in Africa. Journal of Higher Education in Africa, 2(1), 57-91.

Onodugo V.A, Ugwonah G.E, \& Ebinne, E.S. (2010). Social Sciences Research: Principles, Methods and Applications. Enugu: El 'Demak Publishers.

Parlby, D, \& Taylor, R. (2000). The Power of Knowledge: A Business Guide to Knowledge Management. Retrieved from www.kpmgconsulting.com/index.html.

Plessis, M.D. (2007). The Role of knowledge management in innovation. Journal of Knowledge Management, 11(4), 20-29. https://doi.org/10.1108/13673270710762684

Qu, C.X.J, \& Davidson, R.M. (2010). Knowledge Management Problems, Causes and Solutions: Junior Knowledge Workers' Perspectives. $11^{\text {th }}$ Pacific-Asia Conference on Information Systems.

Scarboringh, S.J, \& Preton, J. (1999). Knowledge management: A literature review. London: IPD.

Unyimadu, S.O. (2003). Principles of Research methods. Benin City: Harmoney Publishers.

Wiersma, W. (1969). Research methods in education. Philadelphia: J.B. Lippincott Ct. 